\title{
Ambient Temperature Synthesis of High Enantiopurity N- Protected Peptidyl Ketones by Peptidyl Thiol Ester-Boronic Acid Cross-Coupling
}

\author{
Hao Yang, Hao Li, Rüdiger Wittenberg ${ }^{\dagger}$, Masahiro Egi ${ }^{\ddagger}$, Wenwei Huang§, and Lanny S. \\ Liebeskind \\ Department of Chemistry, Emory University, 1515 Dickey Dr NE, Atlanta, Georgia 30322
}

\begin{abstract}
$\alpha$-Amino acid thiol esters derived from $N$-protected mono-, di-, and tripeptides couple with aryl, $\pi$ electron-rich heteroaryl, or alkenyl boronic acids in the presence of stoichiometric $\mathrm{Cu}(\mathrm{I})$ thiophene-2carboxylate $(\mathrm{CuTC})$ and catalytic $\mathrm{Pd}_{2}(\mathrm{dba})_{3} /$ triethylphosphite to generate the corresponding $\mathrm{N}$ protected peptidyl ketones in good to excellent yields and in high enantiopurity. Triethylphosphite plays a key role as a supporting ligand by mitigating an undesired palladium-catalyzed decarbonylation- $\beta$-elimination of the $\alpha$-amino thiol esters. The peptidyl ketone synthesis proceeds at room temperature under non-basic conditions and demonstrates a high tolerance to functionality.
\end{abstract}

\section{Introduction}

Enantiomerically pure $N$-protected $\alpha$-amino ketones are valuable compounds that can be used as chiral, non-racemic building blocks to construct a great diversity of molecules. ${ }^{1-5}$ Those $\alpha$-amino ketones derived from peptides display a wide range of biological activities. 6 -13

The transformation of $\alpha$-amino acids and small peptides to the corresponding $C$-terminal ketones without epimerization is an ongoing challenge to synthetic chemists. Most methodologies are based on the reaction of basic and nucleophilic organometallic reagents with derivatives of $N$-protected $\alpha$-amino acids such as acid halides, mixed anhydrides, or Weinrebamides. ${ }^{1,4,14-23}$ While this chemistry is of value in the synthesis of simple $\alpha$-amino ketones from $\alpha$-amino acid derivatives, the use of strongly nucleophilic and basic organomagnesium and -lithium reagents precludes the involvement of this chemistry in the synthesis of more complex molecules containing base-sensitive stereogenic centers and nucleophile incompatible functional groups. Hanzawa and Taguchi introduced a novel solution to the problem: the preparation of $\alpha$-amino ketones using acylzirconocene chloride complexes as acyl anion equivalents for the addition to substituted $N$-benzylideneaniline derivatives, but the reactivity is not high and enantioselectivity was not addressed. ${ }^{24}$

\footnotetext{
Email: chemLL1@emory.edu.

Current address: Altana Coatings and Sealants, DS-Chemie GmbH, Straubinger Straße 12, 28219 Bremen, Germany

\$Current address: School of Pharmaceutical Sciences, University of Shizuoka, 52-1 Yada, Shizuoka-shi 422-8526, Japan


20892-3370
}

Supporting Information Available: Experimental procedures, synthesis and characterization of all new compounds (31 pages); scanned copies of ${ }^{1} \mathrm{H}$ and ${ }^{13} \mathrm{C}$ NMR spectra of all new compounds (110 pages). This material is available free of charge via the internet at http://pubs.acs.org. 
To further generalize the synthesis of $\alpha$-amino ketones under mild reaction conditions, a small number of transition metal-catalyzed cross-coupling protocols have been developed. By far the mildest method for the synthesis of $\alpha$-amino ketones from $\alpha$-amino acids and small peptides is the palladium-catalyzed coupling of thiol esters with organozinc reagents developed by Fukuyama and Tokuyama. ${ }^{25,} 26$ Using this cross-coupling procedure, the authors prepared a few examples of $\alpha$-amino ketones from alkylzinc reagents. In a related study, Rovis employed a Ni catalyst for the coupling of $\alpha$-amino acid fluorides with organozinc reagents to give ketones. ${ }^{27}$ While organozinc reagents provide superior functional group compatibility relative to organolithium and organomagnesium reagents, they are, nevertheless, still basic and nucleophilic.

A new, non-basic method for synthesizing ketones from thiol esters and either boronic acids or organostannanes was recently developed. ${ }^{28,29}$ In the presence of a Pd catalyst and copper (I) thiophene-2-carboxylate (CuTC) or related $\mathrm{Cu}(\mathrm{I})$ oxygenates, thiol esters react with boronic acids to give ketones in good to excellent yields. In contrast to organolithium, -magnesium, and -zinc reagents, boronic acids are non-basic and non-nucleophilic, and they are easily prepared and handled. ${ }^{30}$ A great variety of aryl, heteroaryl, and alkenyl boronic acids are now commercially available. Since no base is required and the thiol ester-boronic acid crosscoupling reaction conditions are mild, boronic acids could be superior partners in crosscouplings with peptidyl thiol esters to make functionally-rich and epimerization-sensitive peptidyl ketones. In fact there are related reactions of boronic acids with a variety of acid equivalents such as anhydrides, ${ }^{31-34}$ esters, 35,36 acid fluorides, ${ }^{27}$ and acid chlorides; $37-39$ however, none of the published transformations use acyl reactants or take place under reaction conditions that would be suitable for application to $\mathrm{pH}$ sensitive peptides. Described herein is a study of the scope and limitations of peptidyl ketone synthesis from mono-, di-, and tripeptidyl thiol esters and boronic acids (Scheme 1).

\section{Results and Discussion}

The feasibility of coupling $\alpha$-amino acid thiol esters with boronic acids was first probed using $N$-Boc-protected phenylalanine thiol esters and $\mathrm{PhB}(\mathrm{OH})_{2}$ as depicted in Table 1, entries 1-3.

In contrast to the high yields of ketones typically produced from non-amino acid-derived thiol esters and boronic acids, ${ }^{29} \mathrm{~N}$-Boc-Phe-SR reacted with $\mathrm{PhB}(\mathrm{OH})_{2}$ in the presence of $10 \mathrm{~mol}$ $\% \operatorname{Pd}\left(\mathrm{PPh}_{3}\right)_{4}$ and stoichiometric CuTC to give the corresponding $N$-Boc $\alpha$-amino ketone 2 in very low yield, regardless of the choice of thiol ester -SR moiety. Other mono- $N$-protected amino acid thiol esters were surveyed. While a trityl-protected, basic nitrogen completely prevented coupling (Table 1, entry 7), $\mathrm{N}$-Cbz, $\mathrm{NCF}_{3} \mathrm{CO}$, and $\mathrm{N}$-tosyl gave low yields (Table 1 , entries 4-6). Somewhat improved, but still low to modest yields of ketone could be obtained when the $\alpha$-amino group was doubly protected as the phthalimide or as the $\mathrm{N}, \mathrm{N}$-bis-Boc imide (Table 1, entries 8 and 9). Even though $N, N$-bis-Boc-Phe-SPh (1i) produced an unacceptable yield of cross-coupling product $\mathbf{2 g}$, the experiment allowed the easy isolation and identification of $E-\beta$-( $N, N$-bis-Boc) styrene 3 as a significant side product (Scheme 2$)$. As described below, this observation proved useful in guiding the development of a more effective cross-coupling protocol.

The enimide side product 3 is clearly the result of a facile metal-catalyzed decarbonylation $\beta$-hydride elimination sequence (Scheme 3). Oxidative addition of the thiol ester to $\mathrm{L}_{n} \mathrm{Pd}(0)$ will generate an acylpalladium(II) intermediate $\left(\mathrm{RCOPdL}_{2} \mathrm{SR}\right)$. If transmetalation from the boronic acid to RCOPdL $\mathrm{L}_{2} \mathrm{SR}$ is slow, and if the decarbonylation of the acylpalladium thiolate occurs at a reasonable rate, ${ }^{40,41}$ then the enimide 3 can be generated by the sequence of reactions depicted in the lower half of Scheme 3. 
Crisp observed a similar enimide as the only product in the $\mathrm{Pd}\left(\mathrm{PPh}_{3}\right)_{4}$-catalyzed cross-coupling of $N$-tosyl protected proline acid chloride with vinyl(tri- $n$-butyl)stannane (Scheme 4 ). ${ }^{42}$ In the Crisp system the undesired decarbonylation pathway was inhibited by using $\operatorname{Pd}(\mathrm{dppf}) \mathrm{Cl}_{2}$ as the catalyst.

Decarbonylation can be suppressed by carrying out reactions in the presence of high concentrations of $\mathrm{CO}$, but control experiments of the cross-coupling of an $N$-protected $\alpha$-amino acid thiol ester and a boronic acid conducted under $1 \mathrm{~atm}$ of $\mathrm{CO}$ did not lead to improvements. 43 If the acyl $(M-C O-R)=$ metal alkyl $(M-R)$ equilibrium is not easily perturbed, at least under simple experimental conditions, the reaction outcome might instead be adjusted by influencing the rate of the decarbonylation. Decarbonylation is problematic in the cross-couplings of $\alpha$ amino acid-derived thiol esters with boronic acids because the rate of boron to palladium transmetalation is slow relative to that of decarbonylation. Therefore, to achieve a successful cross-coupling one must either increase the rate of boron to palladium transmetalation or decrease the rate of decarbonylation. Since both the transmetalation and decarbonylation mechanisms require an open coordination site at palladium, ${ }^{44}$ both rates should be influenced by the ligands present in the reaction system (solvent as ligand, added supporting ligands, intramolecular ligation at $\mathrm{Pd}$ by the $\mathrm{N}$-protecting group). If we assume that the decarbonylation and transmetalation pathways can respond differently to variations in the electronic and steric effects of added ligands, it might prove possible to develop a successful cross-coupling by using ligand electronic and steric effects to retard the decarbonylation without hindering the rate of the transmetalation.

With the reaction of $N, N$-bis-Boc-Phe-SPh and $\mathrm{PhB}(\mathrm{OH})_{2} / \mathrm{CuTC}$ depicted in Scheme 2, above, as a starting point, the response of the system to variations in the palladium precatalyst $(\mathrm{Pd}$ $\left.\left(\mathrm{PPh}_{3}\right)_{4}, \mathrm{Pd}_{2}(\mathrm{dba})_{3}, \mathrm{Pd}(\mathrm{dppf}) \mathrm{Cl}_{2}\right)$ with and without various added supporting ligand $\left(\mathrm{PPh}_{3}\right.$, $\mathrm{PMePh}_{2}, \mathrm{PMe}_{2} \mathrm{Ph}, \mathrm{PEt}_{3}$, and $\left.\mathrm{P}(\mathrm{OPh})_{3}\right)$ was explored. A few trends emerged from the study: (1) formation of the undesired enimide side product was suppressed as ligand loadings were increased, and (2) stronger donor ligands gave higher ratios of ketone to enimide, but this was counterbalanced by the recovery of significant portions of unreacted thiol ester in most cases when strong donor ligands were used. Increasing reaction times did not improve conversions, and an increase of the reaction temperature led to an increase in the decarbonylation side reaction. ${ }^{45}$ A bidentate ligand such as diphenylphosphinoferrocene (dppf) completely prevented formation of the ketone and gave a high yield of the undesired enimide, an observation in contrast to the results of Crisp (see Scheme 4, above). ${ }^{42}$ Finally, of the various precatalyst/ligand systems tried, $\mathrm{Pd}\left(\mathrm{PPh}_{3}\right)_{4}: \mathrm{PMe}_{2} \mathrm{Ph}(1: 4$ ratio, or 1:8 palladium/total phosphine) gave the best ratio of ketone to enimide to starting material (61:5:20).

Is the $\mathrm{Pd}\left(\mathrm{PPh}_{3}\right)_{4}: \mathrm{PMe}_{2} \mathrm{Ph}$ (1:4 ratio) catalyst system mentioned above generally useful for $\mathrm{N}$ protected $\alpha$-amino acid thiol ester - boronic acid cross-coupling? The results shown in Table 2 suggest that the answer is a qualified "yes".

Doubly $N$-protected $\alpha$-amino acid thiol esters, such as the $N, N$-bis-Boc and $N$-phthaloyl derivatives gave good yields of ketone products, regardless of the thiol ester -SR group used. Unfortunately, the same $\mathrm{Pd} / \mathrm{PPh}_{3} / \mathrm{PMe}_{2} \mathrm{Ph}$ mixed ligand system did not provide satisfactory cross-coupling yields of the synthetically more important $\mathrm{N}$-Cbz-protected systems (Table 2. entries 9 and 10): $N$-Cbz-Phe-SPh reacted with phenyl boronic acid producing the desired ketone Cbz-Phe-COPh in only $49 \%$ yield along with $25 \%$ of $(E)-\mathrm{PhCH}=\mathrm{CH}-\mathrm{NHCbz}$, 11, the enimide product generated by a decarbonylation- $\beta$-elimination pathway. Changing to a more reactive $p$-nitrophenylthiol ester moiety did not improve the outcome of the reaction (Table 2, entry 10). 


\section{A Room Temperature Synthesis of High Enantiopurity $\mathrm{N}$-Cbz $\alpha$-Amino Ketones}

The data presented in Table 2 demonstrate the capricious nature of the $\mathrm{Pd}\left(\mathrm{PPh}_{3}\right)_{4} / \mathrm{PMe}_{2} \mathrm{Ph}$ catalyst system: it provides good to excellent yields of product with doubly $N$-protected substrates, such as $N, N$-bis-Boc-Phe-SAr and $N$-Phth-Phe-SAr, but not for the synthetically more useful $N$-Cbz (or $N$-Boc) protected $\alpha$-amino thiol esters as substrates. For the widest possible applications in the synthesis of high enantiopurity $\alpha$-amino ketones, it is essential to develop a robust catalyst system that will work with $\alpha$-amino acid thiol esters bearing simple $\mathrm{N}$-Cbz (or $N$-Boc) protecting groups, and then confirm that the cross-coupling proceeds without racemization.

It was noted that high ligand loadings are effective in suppressing the undesired $\beta$-elimination pathway. At the same time, product yields are compromised, most likely because boron to palladium transmetalation will be retarded by (1) an increase in the steric bulk around palladium when large ligands are used, and (2) a decrease in the electrophilicity at palladium when strong donor ligands are used. Does the effectiveness of the doubly $\mathrm{N}$-protected $\mathrm{N}, \mathrm{N}$-bis-Boc and $\mathrm{N}$ phthaloyl $\alpha$-amino acid thiol esters (compared to mono- $N$-protected $\alpha-N$-Cbz or $\alpha-N$-Boc thiol esters) in cross-coupling with minimal decarbonylation direct us to a more general solution? Perhaps this difference can be attributed to the ability of the $N, N$-bis-Boc and $N$-phthaloyl protecting groups to function effectively as the internal equivalent of high loadings of small, but weakly-donating external ligands. This might help maintain 4-coordination at palladium and block decarbonylation, but not sterically or electronically retard transmetalation. If so, the use of a small, weakly-donating, external supporting ligand might be ideal for the palladiumcatalyzed cross-coupling of $N$-Cbz (or $N$-Boc) protected $\alpha$-amino thiol esters. A poorly basic and small phosphine or phosphite would fill coordination sites at $\mathrm{Pd}$, but not attenuate electrophilicity and thus not suppress transmetalation (perhaps directly to a 4-coordinate, 16electron $\mathrm{RCOPdL}_{2} \mathrm{SR}$ intermediate), even at higher ligand loadings.

To test this analysis, cross-coupling experiments (with $N$-Cbz-Phe-SPh, $\mathrm{PhB}(\mathrm{OH})_{2}$ and CuTC) were carried out using $2.5 \mathrm{~mol} \% \mathrm{Pd}_{2}(\mathrm{dba})_{3}$ as a precatalyst in combination with different phosphorus ligands. Among tris-2-furylphosphine, $\mathrm{SbPh}_{3}, \mathrm{P}(\mathrm{OMe})_{3}, \mathrm{P}(\mathrm{OEt})_{3}, \mathrm{P}(\mathrm{OBu})_{3}$, and $\mathrm{P}(\mathrm{OPh})_{3}$ as supporting ligands $(20 \mathrm{~mol} \%$ each $), \mathrm{P}(\mathrm{OEt})_{3}$ delivered the best proved performance. In fact, $2.5 \mathrm{~mol} \% \mathrm{Pd}_{2}(\mathrm{dba})_{3}$ and between $10-20 \mathrm{~mol} \%$ triethylphosphite (1:2 $-1: 4 \mathrm{Pd}: \mathrm{P}$ ratio) proved to be an excellent catalyst system for the cross-coupling of $N$-Cbz protected $\alpha$-amino acid thiol esters (ee $=99 \%$ ) and boronic acids (between room temperature and $30^{\circ} \mathrm{C}$ ) to give the corresponding $N$-Cbz $\alpha$-amino ketones with complete retention of stereochemistry (Table 3). Of significance, higher reaction temperatures caused increased proportions of the undesired decarbonylation side product, suggesting, in retrospect, that the ability of triethylphosphite to support ambient temperature cross-couplings is probably an important factor in the development of a general cross-coupling protocol for the $N$-Cbz protected systems.

A variety of aryl (electron-rich, electron-deficient) and heteroaryl (thienyl and furyl) boronic acids and $(E)$ - $\beta$-styrylboronic acid were efficiently coupled with thiophenyl esters of $N$-Cbz protected $\alpha$-amino acids (Table 3 ). No racemization was detected during the cross-coupling process (the ketonic product was formed with the same ee as the thiol esters precursor) reinforcing, once again, the very mild and non-basic nature of the $\mathrm{Cu}(\mathrm{I})$ carboxylate-mediated couplings of thioorganics and boronic acids. ${ }^{46}$ Moreover, even unprotected tyrosine and tryptophan thiol esters were excellent cross-coupling substrates highlighting the compatibility of unprotected phenolic and indolic residues in this chemistry (Table 3, entries 7-11,13,14). Unfortunately, $\pi$-deficient heteroaromatic boronic acids were not effective substrates giving only low yields of ketone products in this cross-coupling. 


\section{Synthesis of Dipeptidyl and Tripeptidyl Ketones}

The successful synthesis of high enantiopurity $N$-Cbz protected $\alpha$-amino ketones using $2.5 \mathrm{~mol}$ $\% \mathrm{Pd}_{2}(\mathrm{dba})_{3} / 20 \mathrm{~mol} \%$ triethylphosphite and 1.2 equiv of CuTC encouraged an investigation of the synthesis of more complicated structures such as dipeptidyl and tripeptidyl ketones. In the first attempt to synthesize dipeptidyl ketones, $N$-Cbz-(L)-Trp-(L)-Phe-SPh was treated with 1.2 equiv of $p$-methoxyphenyl boronic acid in the presence of $2.5 \mathrm{~mol} \% \operatorname{Pd}_{2}\left(\mathrm{dba}_{3} / 20 \mathrm{~mol} \%\right.$ triethylphosphite/1.2 equiv of CuTC in THF at room temperature (Table 4, entry 1).

The peptidyl ketone formed very rapidly within the first $3 \mathrm{hr}$ of the reaction (according to HPLC monitoring), but the rate of formation of the product then dropped rapidly, even though significant quantities of the thiol ester and the boronic acid were still apparent in HPLC traces. It is relevant that the addition of either CuTC or the boronic acid alone did not induce consumption of the unreacted dipeptide thiol ester. However, charging the reaction mixture with an additional 0.5 equivalent of both $\mathrm{Cu}(\mathrm{I})$ thiophenecarboxylate and the boronic acid reactivated the cross-coupling to generate more ketone and led to almost complete consumption of the dipeptide thiol ester as determined by HPLC. These combined observations were a clear indication that the palladium catalyst was still active, and that the well-known metal-binding affinity of polypeptides and proteins ${ }^{47}$ was not the cause of the low conversion to ketone in this reaction system. However, the experiments gave no insight into why additional boronic acid was a necessary prerequisite to restart the cross-coupling reaction, in particular when HPLC traces indicated that boronic acid was still present in the reaction mixture.

Ultimately, the low conversions to ketone and the ambiguous stoichiometry of the boronic acid were traced to the unpreventable presence of boroxines (boronic acid cyclic trimers) in the boronic acid starting materials. ${ }^{30}$ The synthesis of boronic acids uncontaminated by the corresponding boroxine is highly problematic in most cases. ${ }^{48,} 49$ Furthermore, the facile boroxine $₫$ boronic acid equilibrium at acidic or basic $\mathrm{pH}$ complicates monitoring of the peptidyl thiol ester-boronic acid cross-couplings: HPLC analysis is not able to differentiate between a boronic acid and its boroxine trimer, because the boroxine is easily transformed to the boronic acid by the HPLC eluent system $\left(\mathrm{CH}_{3} \mathrm{CN} / \mathrm{H}_{2} \mathrm{O} / \mathrm{TFA}\right)$.

Under standard Suzuki-Miyaura cross-coupling conditions, the boroxine $₫$ boronic acid equilibrium is not problematic because the boroxine can be shifted to the boronic acid under the reaction conditions by the presence of a requisite base (such as $\mathrm{K}_{2} \mathrm{CO}_{3}$ ) and the higher reaction temperatures typically used. ${ }^{50,51} \mathrm{~A}$ similar rapid in situ boroxine $\leftrightharpoons$ boronic acid interconversion is not feasible under the non-basic, room temperature conditions of the Pdcatalyzed, $\mathrm{Cu}(\mathrm{I})$ carboxylate-mediated cross-couplings of peptidyl thiol esters and boronic acids.

It is known from earlier studies in these laboratories that boronic acids and not boronate esters are uniquely reactive with thiol esters under the mild and non-basic $\mathrm{Pd}$-catalyzed, $\mathrm{Cu}(\mathrm{I})$ carboxylate-mediated conditions. It is therefore assumed that boroxines are likewise unreactive in Pd-catalyzed, $\mathrm{Cu}(\mathrm{I})$ carboxylate-mediated cross-couplings with thioorganics. The requirement of non-basic and ambient temperature reaction conditions for the peptidyl thiol ester cross-couplings therefore precludes any possible rapid in situ conversion of the boroxine to the boronic acid, thus complicating the production of high yields of peptidyl ketones when only a simple stoichiometric quantity of the boronic acid is used.

Indirect proof of the presence of boroxines in the boronic acid samples and the low crosscoupling reactivity of boroxines under the current reaction conditions was obtained. A commercial sample of 4-methoxyphenyl boronic acid showed two pairs of ${ }^{1} \mathrm{H}$ NMR signals in $\mathrm{CDCl}_{3}$, at 8.18 and $7.03 \mathrm{ppm}$ and at 7.70 and $6.95 \mathrm{ppm}$. Addition of $\mathrm{D}_{2} \mathrm{O}$ to the NMR tube led to an increase in the intensity of the 7.70/6.95 peaks and a decrease in intensity of those at 
8.18/7.03. Therefore, the signals at 8.18 and $7.03 \mathrm{ppm}$ are attributed to the boroxine and the others to the boronic acid. Indeed, ${ }^{1} \mathrm{H}$ NMR analysis of the crude reaction mixture that resulted from the transformation depicted in Table 4, entry 1 showed almost complete disappearance of the boronic acid resonances, while those of the boroxine appeared unchanged. Clearly the reactivity of boronic acid is much higher than that of the boroxine under the non-basic and room temperature reaction conditions of this cross-coupling.

Unfortunately, the simple expedient of intentionally adding water to the non-basic crosscoupling reaction mixture did not improve the yield of peptidyl ketone. The collected observations suggest that the use of extra equivalents of freshly prepared boronic acid will be critical to any attempt to improve the yields of the peptidyl ketones. In fact, the simple expedient of increasing the amount of boronic acid compensated for any unreactive boroxine present in the starting material and led to much improved yields of the peptidyl ketones (Table 4, above, compare entries 1-2 and 3-5).

With a mechanism-based rationale for the significance of boronic acid stoichiometry as an important reaction variable in non-basic, room temperature cross-couplings, nine dipeptidyl and tripeptidyl ketones were easily prepared in good to excellent yields (Table 5) using 1.5 -3.0 equiv of boronic acid, $2.5 \mathrm{~mol} \% \mathrm{Pd}_{2}(\mathrm{dba})_{3}, 20 \mathrm{~mol} \% \mathrm{P}(\mathrm{OEt})_{3}$, and 1.5 equiv $\mathrm{CuTC}$ in $\mathrm{THF}$ at room temperature.

The diastereomeric purity of the peptidyl ketone product was identical to that of the starting thiol ester: no epimerization was detectable during the coupling reaction. In general THF was the best of those solvents explored, although a 1:1 THF:hexanes mixed solvent system gave an improved yield of product in one case shown in Table 5 (40\% in THF; 68\% in 1:1 THF:hexanes). This mimics the same solvent effect observed in an earlier project, ${ }^{28}$ where a 1:1 THF:hexanes mixture led to improved yields of ketone in some cases. ${ }^{52}$

\section{Conclusion}

A general and efficient synthesis of high enantiopurity $N$-Cbz $\alpha$-amino mono-, di-, and tripeptidyl ketones was developed from the corresponding thiol esters and aryl, heteroaryl, or alkenyl boronic acids using the catalyst system $\mathrm{Pd}_{2}(\mathrm{dba})_{3} / \mathrm{P}(\mathrm{OEt})_{3} / \mathrm{CuTC}$. Using this mild and versatile cross-coupling reaction, no epimerization was detected throughout the cross-coupling process and the configuration of stereogenic centers was completely preserved. Isolated yields ranged from moderate to excellent. Importantly, unprotected sensitive polar functional groups and variations in electronic nature of boronic acids were well tolerated by the reaction system. It is anticipated that the mild and non-basic features of this new ketone synthesis and its significant functional group compatibility will prove useful for the $C$-terminal or side-chain modification of proteins. Studies are underway to probe that feasibility and to assay the comparative scope, limitations, and utility of organotin reagents in palladium-catalyzed, $\mathrm{Cu}(\mathrm{I})$ carboxylate-mediated cross-couplings of peptidyl thiol esters.

\section{Experimental Section}

\section{Starting Materials}

All boronic acids were obtained from Frontier Scientific Inc. All protected amino acids, $N, N^{\prime}-$ dicyclohexylcarbodiimide (DCC), 1, 1'-carbonyldiimidazole (CDI), $N$-ethyl- $N{ }^{\prime}$-(3dimethylaminopropyl)carbodiimide hydrochloride (EDC), thiophenol, 4-nitrothiophenol, [1,1'-bis(diphenylphosphino)ferrocene] dichloropalladium(II), tetrakis(triphenylphosphine) palladium(0), methyldiphenylphosphine, trimethyl-, tributyl-, and triphenylphosphite, dimethylphenylphosphine, triphenylphosphine, triphenylantimony, triethylphosphine, and tris-2-furylphosphine were purchased from Sigma-Aldrich. $N$-Trifluoroacetylphenylalanine, 
tris(dibenzylideneacetone)dipalladium(0), 1-hydroxybenzotriazole ( $\mathrm{HOBt})$, and triethylphosphite were purchased from Acros. $N$-Tosylphenylalanine was purchased from TCI. Triethylphosphite was purified by distillation at $1 \mathrm{~atm}\left(157^{\circ} \mathrm{C}\right) .{ }^{53} \mathrm{Cu}(\mathrm{I})$ thiophene-2carboxylate (CuTC) was prepared by using a previous procedure. ${ }^{29} \mathrm{~N}, \mathrm{~N}$-Bis-Boc-L-Phe and $\mathrm{N}, \mathrm{N}$-phthaloyl-L-Phe-SPh were prepared according to literature procedures. ${ }^{54,55} \mathrm{~N}$-Protected dipeptide and tripeptide acids were prepared using the standard DCC/HOBt method followed by hydrolysis with lithium hydroxide. 56

$N$-Protected $\alpha$-amino thiol esters of high enantiopurity were prepared using the method of Steglich (DCC/DMAP/EtSH). ${ }^{57}$ For the synthesis of di- and tripeptidyl thiol esters an excess of the thiol (1.5-20.0 equiv) was employed in order to secure high diastereomer purity (de 91 $-99 \%)$.

HPLC analyses were carried out using an Agilent 1100 system with a quaternary pump. Separations were achieved on a Zorbax Eclipse XDB C $84.6 \times 150 \mathrm{~mm}$ column or DAICEL chiral AD, AS, OD reversed phase column (standard elution method: $\lambda=254 \mathrm{~nm}$; Flow: 1.0 $\mathrm{mL} / \mathrm{min} ; \mathrm{T}=30{ }^{\circ} \mathrm{C}$; Gradient: $50 \% \mathrm{H}_{2} \mathrm{O}$ in $\mathrm{CH}_{3} \mathrm{CN}$ during 10 min to $75 \% \mathrm{CH}_{3} \mathrm{CN}$ during $12.5 \mathrm{~min}$ to $100 \% \mathrm{CH}_{3} \mathrm{CN}$ hold for $4.5 \mathrm{~min}$ ).

\section{Representative Examples}

Full details for all compounds can be found in the Supporting Information.

\section{TABLE 3, ENTRY 10}

(-)-L-Cbz-Tryptophan Thiophenyl Ester: $N$-Cbz-L-Tryptophan $(3.384 \mathrm{~g}, 10.0 \mathrm{mmol})$ and thiophenol $(1.322 \mathrm{~g}, 12.0 \mathrm{mmol})$ were dissolved in dry ethyl acetate $(20 \mathrm{~mL})$ at $0{ }^{\circ} \mathrm{C}$, then $N, N^{\prime}$-dicyclohexylcarbodiimide $(2.478 \mathrm{~g}, 12.0 \mathrm{mmol})$ was added. The reaction was stirred at $0{ }^{\circ} \mathrm{C}$ for the first $30 \mathrm{~min}$ and then at room temperature overnight. Progress was monitored by HPLC analysis. At the end of the reaction a few drops of $50 \%$ acetic acid in ethyl acetate were added. The reaction mixture was filtered through a short plug of Celite ${ }^{\mathrm{TM}}$ and concentrated in vacuo. The crude product was triturated with hexanes to remove excess thiophenol, dissolved in $\mathrm{MeOH}$, and crystallized by addition of water. Filtration and drying at high vacuum afforded $(-)$-L-Cbz-tryptophan thiophenyl ester as a white solid. Yield: $4.127 \mathrm{~g}(96 \%)$. TLC $\left(\mathrm{R}_{f}=0.22\right.$, silica gel, $25 \%$ ethyl acetate in hexanes). $\mathrm{Mp}=47-51{ }^{\circ} \mathrm{C}$. HPLC Chiral OD-RH standard method: $\mathrm{L}$-isomer $\mathrm{t}_{\mathrm{R}}=14.2 \mathrm{~min}$, D-isomer $\mathrm{t}_{\mathrm{R}}=15.2 \mathrm{~min}$, ee $>99 \% .{ }^{1} \mathrm{H} \mathrm{NMR}(400 \mathrm{MHz}$, $\left.\mathrm{CDCl}_{3}\right) \delta 8.10(\mathrm{br} \mathrm{s}, 1 \mathrm{H}), 7.56(\mathrm{~d}, J=8.1 \mathrm{~Hz}, 1 \mathrm{H}), 7.42-7.25(\mathrm{~m}, 11 \mathrm{H}), 7.23(\mathrm{t}, J=7.2 \mathrm{~Hz}$, $1 \mathrm{H}), 7.12(\mathrm{t}, J=7.5 \mathrm{~Hz}, 1 \mathrm{H}), 7.04(\mathrm{~d}, J=2.2 \mathrm{~Hz}, 1 \mathrm{H}), 5.33(\mathrm{~d}, J=9.1 \mathrm{~Hz}, 1 \mathrm{H}), 5.14(\mathrm{~s}, 2 \mathrm{H})$, $4.92-4.85(\mathrm{~m}, 1 \mathrm{H}), 3.43(\mathrm{dd}, J=15.0,5.9 \mathrm{~Hz}, 1 \mathrm{H}), 3.32(\mathrm{dd}, J=14.7,5.6 \mathrm{~Hz}, 1 \mathrm{H}) .{ }^{13} \mathrm{C}$ NMR $\left(100 \mathrm{MHz}, \mathrm{CDCl}_{3}\right) \delta 199.6,155.8,136.1,136.1,134.6,129.5,129.2,128.5,128.2,128.0,127.4$, 127.1, 123.2, 122.3, 119.8, 118.8, 111.3, 109.2, 67.2, 61.0, 28.2. IR (neat, $\left.\mathrm{cm}^{-1}\right) 3405$ (m), 3061 (w), 1698 (vs), 1502 (s), 1455 (m), 1239 (s), 1061 (m), 741 (s). HRMS (FAB) Calcd for $\mathrm{C}_{25} \mathrm{H}_{22} \mathrm{~N}_{2} \mathrm{O}_{3} \mathrm{SLi}\left([\mathrm{M}+\mathrm{Li}]^{+}\right)$: 437.1511. Found: 437.1515. $[\alpha]^{20} \mathrm{D}=-68.4\left(\mathrm{c}=1.02, \mathrm{CHCl}_{3}\right)$.

(+)-(2S)-1-(3-Acetylphenyl)-2-benzyloxycarbonylamino-3-(1H-indol-3-yl)-propan-1one: $N$-Cbz-ь-Trp-SPh ( $86 \mathrm{mg}, 0.2 \mathrm{mmol}$ ), 3-acetylphenylboronic acid (39 $\mathrm{mg}, 0.24 \mathrm{mmol}$ ), CuTC (46 mg, $0.24 \mathrm{mmol})$, and $\operatorname{Pd}_{2}(\mathrm{dba})_{3}(4 \mathrm{mg}, 5 \mu \mathrm{mol})$ were placed under an argon atmosphere. THF ( $3 \mathrm{~mL}$, degassed and dried over $4 \AA$ molecular sieves $)$ and $\mathrm{P}(\mathrm{OEt})_{3}(3.4 \mu \mathrm{l}$, $20 \mu \mathrm{mol}, 10 \mathrm{~mol} \%$ ) were added and the mixture was stirred at $30{ }^{\circ} \mathrm{C}$ overnight. The reaction progress was monitored by HPLC analysis. For work-up, the reaction mixture was diluted with $25 \mathrm{~mL}$ of ether, washed with saturated aqueous $\mathrm{NaHCO}_{3}$ and brine $(15 \mathrm{~mL}$ each), followed by drying over $\mathrm{MgSO}_{4}$. The drying agent was filtered off through a short plug of silica gel (to aid removal of metal containing products) and the filtrate was concentrated under vacuum. The crude product was purified by preparative TLC (silica gel, $20 \times 20 \mathrm{~cm}, 2 \mathrm{~mm}, 33 \%$ ethyl acetate 
in hexanes) to afford (+)-(2S)-1-(3-acetyl-phenyl)-2-benzyloxycarbonylamino-3-(1H-indol-3yl)-propan-1-one as a yellow oil. Yield: $60 \mathrm{mg}(68 \%)$. TLC $\left(\mathrm{R}_{f}=0.45\right.$, silica gel, 50\% ethyl acetate in hexanes). HPLC Chiral AS-RH standard method: L-isomer $t_{\mathrm{R}}=7.3 \mathrm{~min}$, D-isomer $\mathrm{t}_{\mathrm{R}}=6.8 \mathrm{~min}, \mathrm{ee}>99 \% .{ }^{1} \mathrm{H}$ NMR $\left(400 \mathrm{MHz}, \mathrm{CDCl}_{3}\right) \delta 8.22(\mathrm{~s}, 1 \mathrm{H}), 8.09(\mathrm{~d}, J=7.9 \mathrm{~Hz}, 1 \mathrm{H})$, $8.03(\mathrm{~m}, 2 \mathrm{H}), 7.48(\mathrm{~m}, 2 \mathrm{H}), 7.40-7.28(\mathrm{~m}, 5 \mathrm{H}), 7.25(\mathrm{~d}, J=7.9 \mathrm{~Hz}, 1 \mathrm{H}), 7.14(\mathrm{~m}, 1 \mathrm{H}), 7.05$ (app t, $J=7.5 \mathrm{~Hz}, 1 \mathrm{H}), 6.73(\mathrm{~d}, J=2.2 \mathrm{~Hz}, 1 \mathrm{H}), 5.85(\mathrm{~d}, J=7.6 \mathrm{~Hz}, 1 \mathrm{H}), 5.71(\mathrm{~m}, 1 \mathrm{H}), 5.17$ and $5.13(\mathrm{AB} \mathrm{q}, J=12.1 \mathrm{~Hz}, 2 \mathrm{H}), 3.33(\mathrm{~m}, 2 \mathrm{H}), 2.41(\mathrm{~s}, 3 \mathrm{H}) .{ }^{13} \mathrm{C} \mathrm{NMR}\left(100 \mathrm{MHz}, \mathrm{CDCl}_{3}\right)$ $\delta$ 198.4, 197.2, 155.8, 137.2, 136.3, 135.9, 135.4, 132.6, 129.0, 128.5, 128.2, 128.1, 127.3, 122.9, 122.2, 119.7, 118.6, 111.1, 109.7, 67.0, 56.0, 29.4, 26.4. IR (neat, $\left.\mathrm{cm}^{-1}\right) 3350$ (br m), 3061 (w), 2926 (w), 1683 (vs), $1598(\mathrm{~m}), 1428(\mathrm{~m}), 1278(\mathrm{~s}), 1212(\mathrm{~s}), 1061(\mathrm{~m}), 745(\mathrm{~m}), 698$ (m). HRMS (FAB) Calcd for $\mathrm{C}_{27} \mathrm{H}_{25} \mathrm{~N}_{2} \mathrm{O}_{4}\left([\mathrm{M}+\mathrm{H}]^{+}\right)$: 441.1809. Found: 441.1815. $[\alpha]^{20}{ }_{\mathrm{D}}=$ $+113.4\left(\mathrm{c}=1.46, \mathrm{CHCl}_{3}\right)$.

\section{TABLE 5. ENTRY 6}

(-)-N-Cbz-L-Tryptophan-L-Phenylalanine Thiophenyl Ester: To a solution of the $N$-Cbz-LTrp-L-Phe $(945 \mathrm{mg}, 2.0 \mathrm{mmol})$ in EtOAc $(20 \mathrm{~mL})$ was added HOBt $(408 \mathrm{mg}, 3.0 \mathrm{mmol})$, thiophenol (340 mg, $3.0 \mathrm{mmol}$ ), followed by the dropwise addition of 1,3-

dicyclohexylcarbodiimide ( $415 \mathrm{mg}, 2.0 \mathrm{mmol}$, in $10 \mathrm{~mL}$ EtOAc) at $0{ }^{\circ} \mathrm{C}$ for 30 minutes. The reaction progress was monitored by HPLC analysis. After stirring overnight at room temperature, the reaction was treated with $1 \mathrm{~mL}$ acetic acid (50\% in ethyl acetate) for $30 \mathrm{~min}$. The mixture was filtered through Celite ${ }^{\mathrm{TM}}$ and the organic phase was washed with $1 \mathrm{M} \mathrm{HCl}$, $\mathrm{NaHCO}_{3}$ solution, and brine, dried over $\mathrm{MgSO}_{4}$, filtered, and evaporated. The crude was purified by recrystallization from $\mathrm{MeOH}$ (induced by addition of water) afforded $N$-Cbz-L-TrpL-Phe-SPh as a white solid. Yield: $1.066 \mathrm{~g}(95 \%)$. TLC $\left(\mathrm{R}_{f}=0.54\right.$, silica gel, $50 \%$ ethyl acetate in hexanes). $\mathrm{Mp}=159-160^{\circ} \mathrm{C}$. HPLC Chiral OD-RH standard method: $\mathrm{L}_{\mathrm{L}, \mathrm{L}}$-isomer $\mathrm{t}_{\mathrm{R}}=13.8$ min, de $=91 \%$ (determined by $\left.{ }^{1} \mathrm{H}-\mathrm{NMR}\right) .{ }^{1} \mathrm{H}$ NMR $\left(400 \mathrm{MHz}, \mathrm{CDCl}_{3}\right) \delta 7.99(\mathrm{~s}, 1 \mathrm{H}), 7.71$ $(\mathrm{d}, 1 \mathrm{H}), 7.44-7.13(\mathrm{~m}, 16 \mathrm{H}), 6.99(\mathrm{~s}, 1 \mathrm{H}), 6.86(\mathrm{~d}, J=6.0 \mathrm{~Hz}, 2 \mathrm{H}), 6.24(\mathrm{~d}, J=6.4 \mathrm{~Hz}, 1 \mathrm{H})$, $5.36(\mathrm{~s}, 1 \mathrm{H}), 5.10(\mathrm{~s}, 2 \mathrm{H}), 4.96(\mathrm{dd}, J=14.8,8.4 \mathrm{~Hz}, 1 \mathrm{H}), 4.55(\mathrm{~s}, 1 \mathrm{H}), 3.34(\mathrm{~s}, 1 \mathrm{H}), 3.16(\mathrm{dd}$, $J=14.8,7.2 \mathrm{~Hz}, 1 \mathrm{H}), 2.95(\mathrm{~d}, J=6.8 \mathrm{~Hz}, 2 \mathrm{H}) .{ }^{13} \mathrm{C} \mathrm{NMR}\left(150 \mathrm{MHz}, \mathrm{CDCl}_{3}\right) \delta 197.8,171.4$, 156.2, 136.4, 135.3, 134.8, 129.8, 129.5, 128.8, 128.7, 128.4, 128.3, 127.4, 127.0, 123.6, 122.7, 120.2, 119.1, 111.5, 110.4, 67.3, 59.8, 55.4, 38.3, 28.2. IR (neat, $\left.\mathrm{cm}^{-1}\right) 3405(\mathrm{w}), 3304(\mathrm{w})$, $3061(\mathrm{~m}), 3034(\mathrm{~m}), 2926(\mathrm{~m}), 1698(\mathrm{~s}), 1664(\mathrm{~s}), 1513(\mathrm{~s}), 1455(\mathrm{~m}), 1343(\mathrm{~m}), 1231(\mathrm{~s}), 1054$ (m), $1027(\mathrm{~m}), 741$ (s). HRMS (FAB) Calcd for $\mathrm{C}_{34} \mathrm{H}_{31} \mathrm{~N}_{3} \mathrm{O}_{4} \mathrm{SLi}\left([\mathrm{M}+\mathrm{Li}]^{+}\right)$: 584.2195. Found: 584.2179. $[\alpha]^{20} \mathrm{D}=-28.8\left(\mathrm{c}=0.57, \mathrm{CHCl}_{3}\right)$.

\section{(+)-2-(S)-Benzyloxycarbonylamino- $N$-[1-(S)-benzyl-2-(4-methoxy-phenyl)-2-oxo-}

ethyl]-3-(1H-indol-3-yl)-propionamide: A mixture of $N$-Cbz-L-Trp--_-Phe-SPh $(57 \mathrm{mg}, 0.1$ $\mathrm{mmol}$ ), $p$-methoxylphenylboronic acid (30 mg, $0.20 \mathrm{mmol}$ ), CuTC (29 mg, $0.15 \mathrm{mmol}$ ), and $\mathrm{Pd}_{2}(\mathrm{dba})_{3}(2 \mathrm{mg}, 2.5 \mu \mathrm{mol})$ were placed under an argon atmosphere. THF ( $3 \mathrm{~mL}$, degassed and dried over $4 \AA$ molecular sieves) and triethylphosphite $(20 \mathrm{~mol} \%, 3.4 \mu \mathrm{l}, 20 \mu \mathrm{mol})$ were added and the mixture was stirred at room temperature until the $N$-Cbz-peptidyl-thiophenyl ester was consumed $(3 \mathrm{~h})$. Reaction progress was monitored by HPLC analyses. The reaction mixture was diluted with ether $(25 \mathrm{~mL})$, washed with $\mathrm{NaHCO}_{3}$ solution and brine $(15 \mathrm{~mL}$ each) then dried over $\mathrm{MgSO}_{4}$. The drying agent was filtered off through a short plug of silica gel (to aid removal of metal containing products) and concentrated under vacuum using a rotary evaporator. The crude material was subjected to purification by preparative TLC (silica gel, $20 \times 20 \mathrm{~cm}, 2 \mathrm{~mm}, 50 \%$ ethyl acetate in hexanes) to afford (+)-2-(S)-benzyloxycarbonylamino$\mathrm{N}$-[1-(S)-benzyl-2-(4-methoxy-phenyl)-2-oxo-ethyl]-3-(1H-indol-3-yl)-propionamide as a colorless oil. Yield: $41 \mathrm{mg}(72 \%)$. TLC $\left(\mathrm{R}_{f}=0.32\right.$, silica gel, 50\% ethyl acetate in hexanes). HPLC Chiral OD-RH: L, L-isomer $t_{R}=13.3$ min, L, D-isomer $t_{R}=12.7 \mathrm{~min}, \mathrm{de}=91 \% .{ }^{1} \mathrm{H} \mathrm{NMR}$ $\left(400 \mathrm{MHz}, \mathrm{CDCl}_{3}\right) \delta 8.09(\mathrm{~s}, 1 \mathrm{H}), 7.83(\mathrm{~d}, J=8.4 \mathrm{~Hz}, 2 \mathrm{H}), 7.63(\mathrm{~d}, J=7.2 \mathrm{~Hz}, 1 \mathrm{H}), 7.36-6.91$ (m, 14H), $6.74(\mathrm{~d}, J=7.2 \mathrm{~Hz}, 2 \mathrm{H}), 6.61(\mathrm{~d}, J=7.6 \mathrm{~Hz}, 1 \mathrm{H}), 5.58(\mathrm{~m}, 2 \mathrm{H}), 5.13(\mathrm{~m}, 2 \mathrm{H}), 4.54$ 
$(\mathrm{d}, J=6.0 \mathrm{~Hz}, 1 \mathrm{H}), 3.89(\mathrm{~s}, 3 \mathrm{H}), 3.33(\mathrm{~m}, 1 \mathrm{H}), 3.12(\mathrm{~m}, 2 \mathrm{H}), 2.88(\mathrm{dd}, J=14.0,5.2 \mathrm{~Hz}$, 1H). ${ }^{13} \mathrm{C} \mathrm{NMR}\left(100 \mathrm{MHz}, \mathrm{CDCl}_{3}\right) \delta$ 195.6, 170.9, 164.3, 156.1, 136.4, 135.7, 131.2, 129.6, $128.7,128.4,128.3,128.3,127.6,127.0,123.4,122.4,119.9,118.9,114.2,111.4,110.5,67.2$, 55.7, 55.7, 54.6, 39.1, 28.8. IR (neat, $\left.\mathrm{cm}^{-1}\right) 3327$ (w), $3061(\mathrm{~m}), 3034(\mathrm{~m}), 2957$ (m), 2934 (m), $1710(\mathrm{~s}), 1652(\mathrm{~s}), 1513(\mathrm{~s}), 1455(\mathrm{~m}), 1343(\mathrm{~m}), 1258(\mathrm{~s}), 1170(\mathrm{~m}), 1027(\mathrm{~m}), 737(\mathrm{~s})$. HRMS (FAB) Calcd for $\mathrm{C}_{35} \mathrm{H}_{33} \mathrm{~N}_{3} \mathrm{O} 5 \mathrm{Li}\left([\mathrm{M}+\mathrm{Li}]^{+}\right): 582.2580$. Found: 582.2552 . $[\alpha]^{20}{ }_{\mathrm{D}}=$ $+13.2\left(\mathrm{c}=0.68, \mathrm{CHCl}_{3}\right)$.

\section{Supplementary Material}

Refer to Web version on PubMed Central for supplementary material.

\section{Acknowledgement}

The National Institutes of General Medical Sciences, DHHS supported this investigation through grant No. GM066153.

\section{References}

1. Ooi T, Takeuchi M, Kato D, Uematsu Y, Tayama E, Sakai D, Maruoka K. J. Am. Chem. Soc 2005;127:5073-5083. [PubMed: 15810842]

2. Tokuyama H, Yokoshima S, Yamashita T, Lin S-C, Li L, Fukuyama T. J. Braz. Chem. Soc 1998;9:381387.

3. Gamble MP, Giblin GMP, Montana JG, O'Brien P, Ockendon TP, Taylor RJK. Tetrahedron Lett 1996;37:7457-7460.

4. Myers AG, Yoon T. Tetrahedron Lett 1995;36:9429-9432.

5. West FG, Glaeske KW, Naidu BN. Synthesis 1993:977-980.

6. Tripathy R, Ator MA, Mallamo JP. Bioorg. Med. Chem. Lett 2000;10:2315-2319. [PubMed: 11055346]

7. Marquis RW, et al. Bioorg. Med. Chem 1999;7:581-588. [PubMed: 10353637]

8. Hruby VJ, Li G, Haskell-Luevano C, Shenderovich M. Peptide Science 1997;43:219-266. [PubMed: 9277134]

9. Calabretta R, Giordano C, Gallina C, Morea V, Consalvi V, Scandurra R. Eur. J. Med. Chem 1995;30:931-941.

10. Dragovich PS, et al. Bioorg. Med. Chem. Lett 2000;10:45-48. [PubMed: 10636240]

11. Eda M, Ashimori A, Akahoshi F, Yoshimura T, Inoue Y, Fukaya C, Nakajima M, Fukuyama H, Imada T, Nakamura N. Bioorg. Med. Chem. Lett 1998;8:919-924. [PubMed: 9871512]

12. Wagner BM, Smith RA, Coles PJ, Copp LJ, Ernest MJ, Krantz A. J. Med. Chem 1994;37:1833-1840. [PubMed: 8021922]

13. Gante J. Angew. Chem 1994;106:1780-1802.

14. Liu J, Ikemoto N, Petrillo D, Armstrong JD. Tetrahedron Lett 2002;43:8223-8226.

15. Bonini BF, Comes-Franchini M, Fochi M, Mazzanti G, Ricci A, Varchi G. Synlett 1998:1013-1015.

16. Paleo MR, Calaza MI, Sardina FJ. J. Org. Chem 1997;62:6862-6869.

17. Sengupta S, Mondal S, Das D. Tetrahedron Lett 1999;40:4107-4110.

18. Klix RC, Chamberlin SA, Bhatia AV, Davis DA, Hayes TK, Rojas FG, Koops RW. Tetrahedron Lett 1995;36:1791-1794.

19. Hamby JM, Hodges JC. Heterocycles 1993;35:843-850.

20. Reetz MT. Angew. Chem., Int. Ed. Engl 1991;30:1531-1546.

21. Knudsen CG, Rapoport H. J. Org. Chem 1983;48:2260-2266.

22. Buckley TF III, Rapoport H. J. Am. Chem. Soc 1981;103:6157-6163.

23. Nahm S, Weinreb SM. Tetrahedron Lett 1981;22:3815-3818.

24. Kakuuchi A, Taguchi T, Hanzawa Y. Tetrahedron Lett 2001;42:1547-1549. 
25. Fukuyama T, Tokuyama H. Aldrichimica Acta 2004;37:87-96.

26. Tokuyama H, Yokoshima S, Yamashita T, Fukuyama T. Tetrahedron Lett 1998;39:3189-3192.

27. Zhang Y, Rovis T. J. Am. Chem. Soc 2004;126:15964-15965. [PubMed: 15584721]

28. Wittenberg R, Srogl J, Egi M, Liebeskind LS. Org. Lett 2003;5:3033-3035. [PubMed: 12916974]

29. Liebeskind LS, Srogl J. J. Am. Chem. Soc 2000;122:11260-11261.

30. Hall, DG. Structure, Properties, and Preparation of Boronic Acid Derivatives. Overview of Their Reactions and Applications.. In: Hall, DG., editor. Boronic Acids. WILEY-VCH Verlag GmbH \& Co KGaA; Weinheim: 2005.

31. Xin B, Zhang Y, Cheng K. J. Org. Chem 2006;71:5725-5731. [PubMed: 16839154]

32. Kakino R, Yasumi S, Shimizu I, Yamamoto A. Bull. Chem. Soc. Jpn 2002;75:137-148.

33. Gooßen LJ, Ghosh K. Angew. Chem., Int. Ed. Engl 2001;40:3458-3460. [PubMed: 11592170]

34. Gooßen LJ, Ghosh K. Chem. Commun 2001:2084-2085.

35. Tatamidani H, Kakiuchi F, Chatani N. Org. Lett 2004;6:3597-3599. [PubMed: 15387557]

36. Tatamidani H, Yokota K, Kakiuchi F, Chatani N. J. Org. Chem 2004;69:5615-5621. [PubMed: 15307730]

37. Urawa Y, Ogura K. Tetrahedron Lett 2003;44:271-273.

38. Haddach M, McCarthy JR. Tetrahedron Lett 1999;40:3109-3112.

39. Bumagin NA, Korolev DN. Tetrahedron Lett 1999;40:3057-3060.

40. Osakada K, Yamamoto T, Yamamoto A. Tetrahedron Lett 1987;28:6321-6324.

41. Kato T, Kuniyasu H, Kajiura T, Minami Y, Ohtaka A, Kinomoto M, Terao J, Kurosawa H, Kambe N. Chem. Commun 2006:868-870.

42. Crisp GT, Bubner TP. Synth. Commun 1990;20:1665-1670.

43. Reactions carried out at high pressures of $\mathrm{CO}$ might well be successful, but were not pursued in favor of perturbing the reaction outcome through other variables as described in the text.

44. 4-Coordinate, square planar palladium(II) complexes are coordinatively unsaturated (16-electron), but often react by further ligand loss to a 3-coordinate, 14-electron intermediate.

45. Extending the reaction time from 16 to $36 \mathrm{hr}$ or raising the reaction temperature from $50{ }^{\circ} \mathrm{C}$ to $60^{\circ}$ $\mathrm{C}$ did not increase the yield of the ketone. However, an effective reaction was resumed when additional $\mathrm{CuTC}$ and phenylboronic acid were added to the reaction mixture after $14 \mathrm{hr}$, an indication that the Pd catalyst was still robust. For example, a mixture of thiol ester $N, N$-bis-Boc-phenylalanine p-chlorophenylthiol ester (56.4 mg, $0.11 \mathrm{mmol}, 1.0$ equiv), CuTC (32.7 mg, $0.17 \mathrm{mmol}, 1.5$ equiv), phenyl boronic acid (21.4 mg, $0.18 \mathrm{mmol}, 1.5$ equiv), $\mathrm{Pd}_{2}(\mathrm{dba})_{3}(5.6 \mathrm{mg}, 0.061 \mathrm{mmol}, 0.05$ equiv), $\mathrm{PPh}_{3}$ (11.9 mg, $0.045 \mathrm{mmol}, 0.4$ equiv), and $\mathrm{PMe}_{2} \mathrm{Ph}(6.5 \mu \mathrm{L}, 0.045 \mathrm{mmol}, 0.4$ equiv) in $3 \mathrm{~mL}$ of dry THF was stirred at $50{ }^{\circ} \mathrm{C}$ for $14 \mathrm{hr}$. Then, additional CuTC (21.9 mg, $0.11 \mathrm{mmol}, 1.0$ equiv), phenyl boronic acid ( $14.1 \mathrm{mg}, 0.11 \mathrm{mmol}, 1.0$ equiv) and $1.0 \mathrm{~mL}$ of dry THF were added. The reaction was stirred for another 8 hours at $50{ }^{\circ} \mathrm{C}$. After the aqueous work-up, the yield of the ketone (81\%) was determined by proton NMR using pentamethylbenzene as an internal standard.

46. Lory P, Gilbertson SR. Chemtracts 2005;18:569-583.

47. Sigel H, Martin RB. Chem. Rev 1982;82:385-426.

48. Snyder HR, Konecky MS, Lennarz WJ. J. Am. Chem. Soc 1958;80:3611-3615.

49. Snyder HR, Kuck JA, Johnson JR. J. Am. Chem. Soc 1938;60:105-111.

50. Bedford RB. Chem. Commun 2003:1787-1796.

51. Miyaura N, Suzuki A. Chem. Rev 1995;95:2457-2483.

52. THF:hexanes solvent mixtures were used to maintain a low concentration of the active $\mathrm{Cu}(\mathrm{I})$ carboxylate in solution throughout the course of the cross-coupling reaction. $\mathrm{Cu}(\mathrm{I})$ carboxylate that is not complexed to the thiol ester or to the putative palladium(II) thiolate catalytic intermediate concentrations leads to competitive destruction of the boronic acid by a $\mathrm{Cu}$-mediated protodeborylation.

53. Taira K, Gorenstein DG. Tetrahedron Lett 1984;40:3215-3222.

54. Gunnarsson K, Ragnarsson U. Acta Chem. Scand., Ser. A 1990;44:944-951.

55. Weygand F, Kaelicke J. Chem. Ber 1962;95:1031-1038.

56. Koenig W, Geiger R. Chem. Ber 1970;103:788-798. [PubMed: 5436656] 
57. Neises B, Steglich W. Angew. Chem., Int. Ed. Engl 1978;17:522-524. 




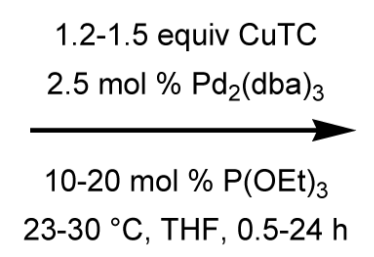

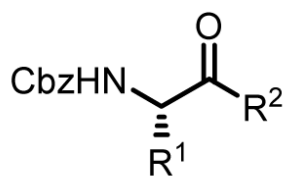

no racemization
Yield: $48-99 \%$ ee: $99 \%$ de: $91-99 \%$

Scheme 1.

Peptidyl Ketones from Peptidyl Thiol Esters and Boronic Acids 
<smiles>O=C(C(=O)C(Br)c1ccccc1)c1ccccc1</smiles>

$1 \mathrm{i}$
1.5 equiv CuTC $\underset{10 \mathrm{~mol} \% \mathrm{Pd}\left(\mathrm{PPh}_{3}\right)_{4}}{\stackrel{1.5 \text { equiv } \mathrm{PhB}(\mathrm{OH})_{2}}{\longrightarrow}}$ $\mathrm{THF}, 50^{\circ} \mathrm{C}$<smiles>CC(C)(C)OCC(Br)C(=O)c1ccccc1</smiles>

2g $28 \%$
$\mathrm{Ph} \sim \mathrm{N}(\mathrm{Boc})_{2}+$ Recovered 1i
$320 \%$

Scheme 2.

Identification of a Decarbonylation Side Product 




Scheme 3.

The Decarbonylation Pathway 


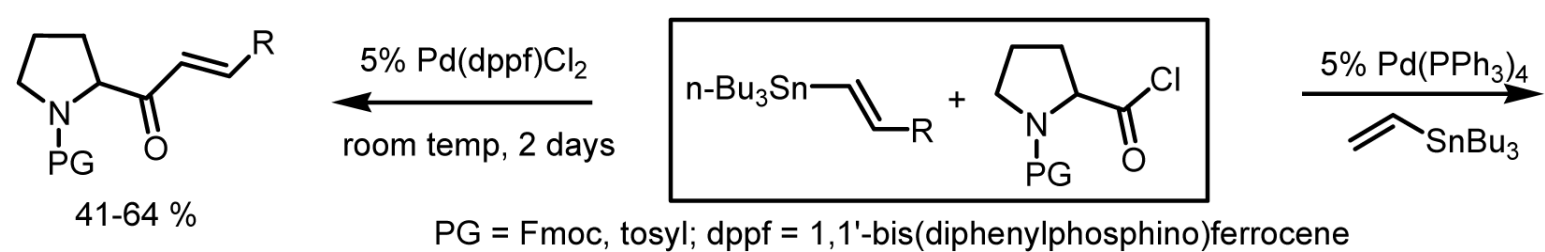

Scheme 4.

Precedent for the Decarbonylation Pathway 


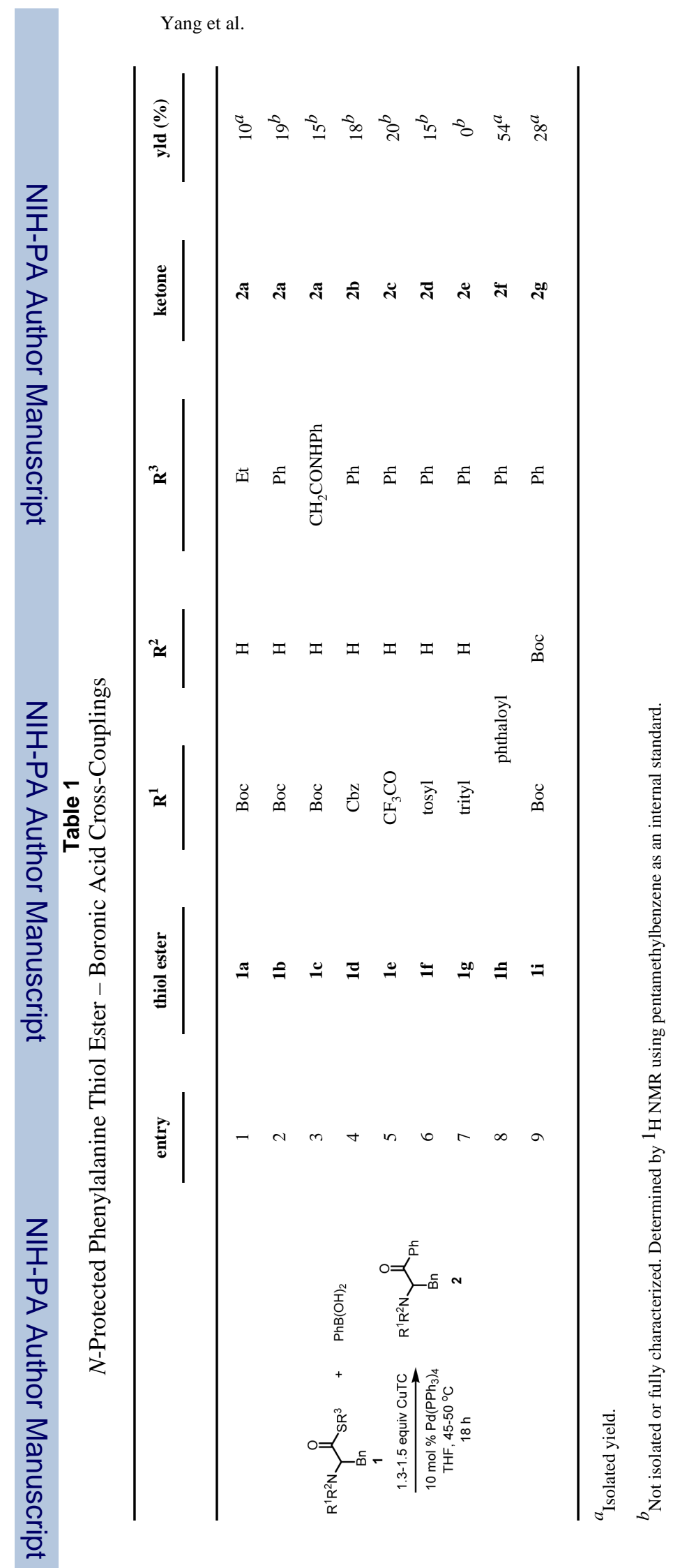




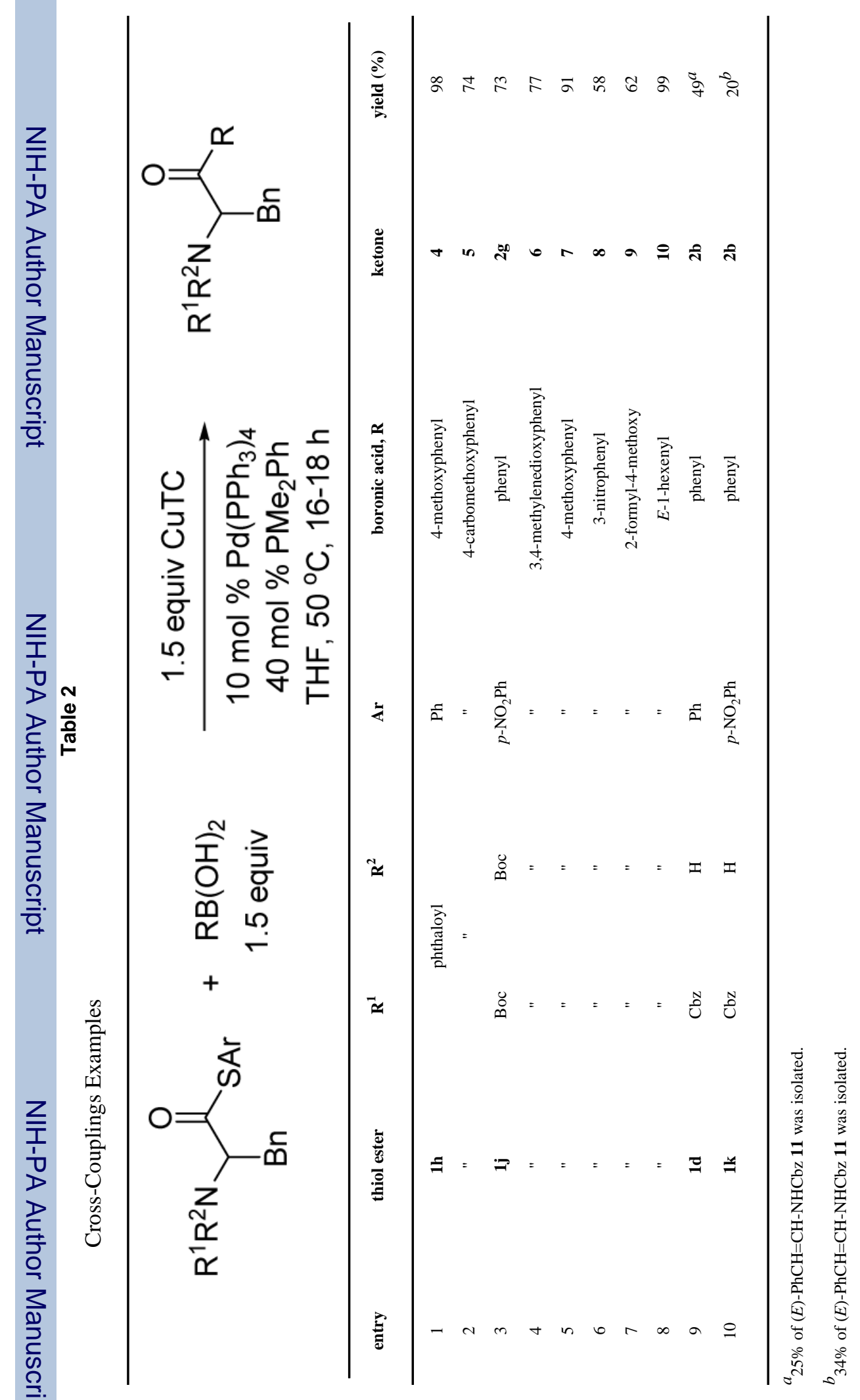




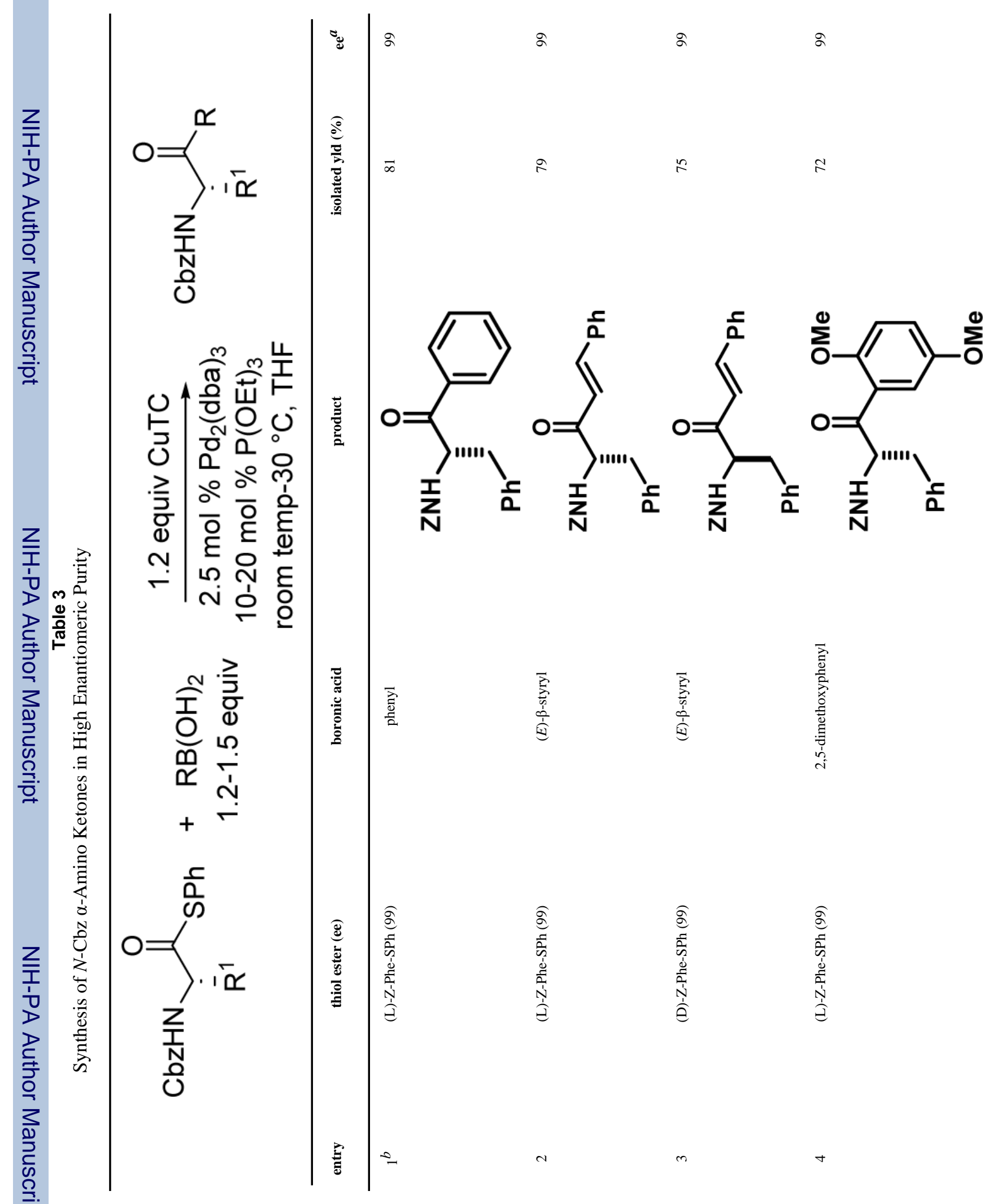




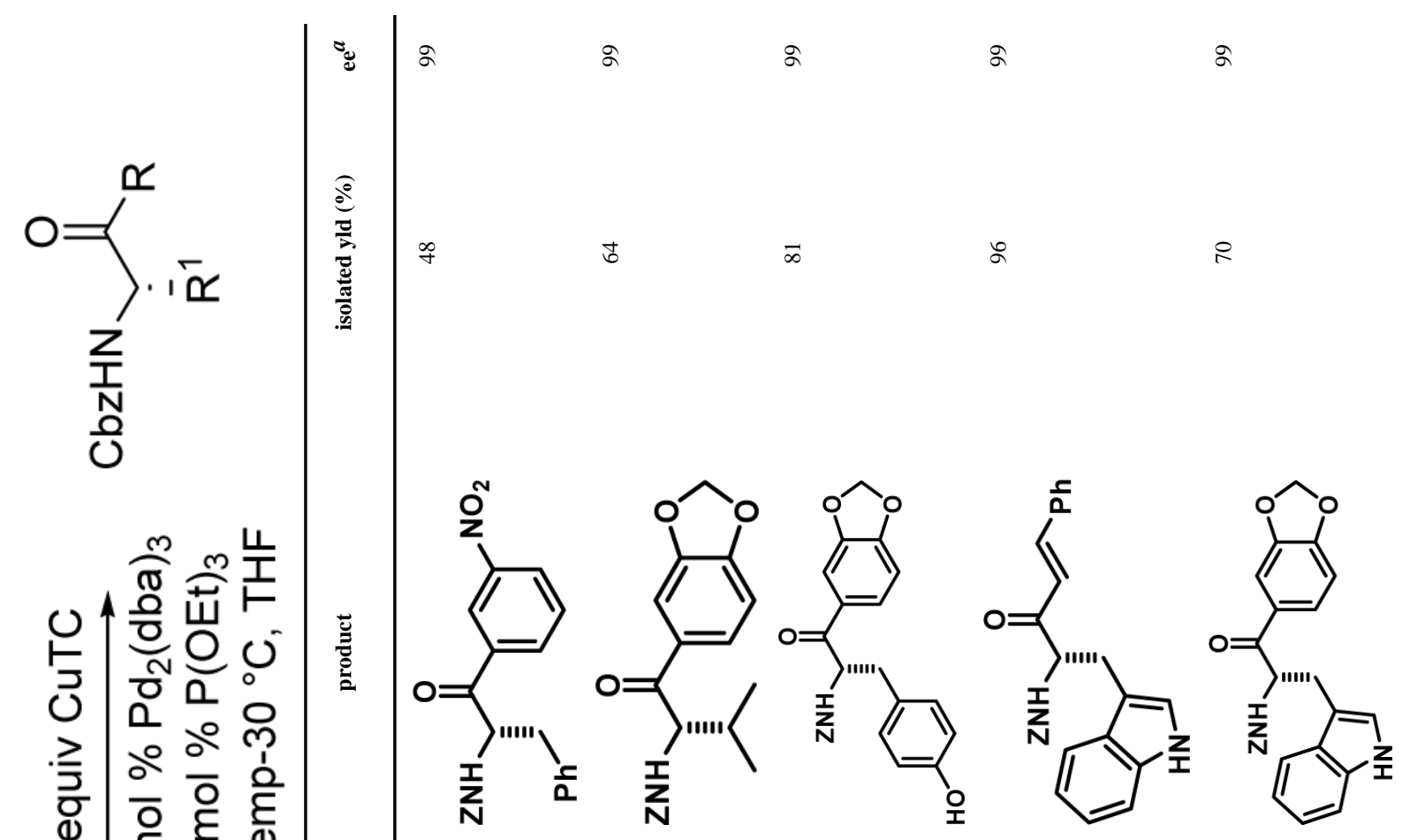
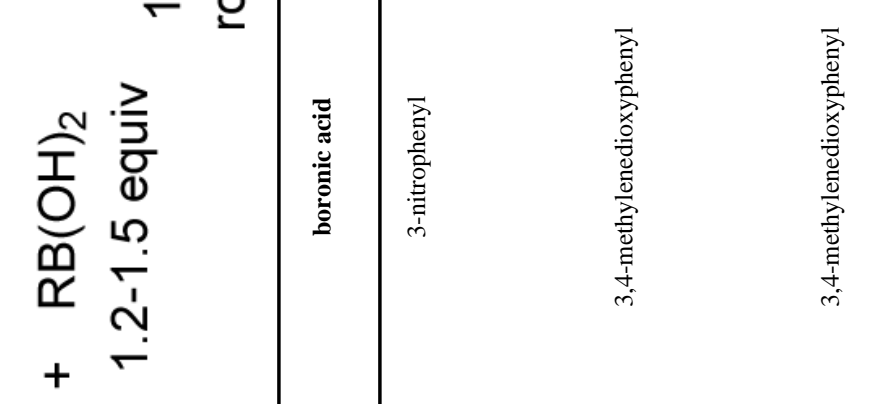


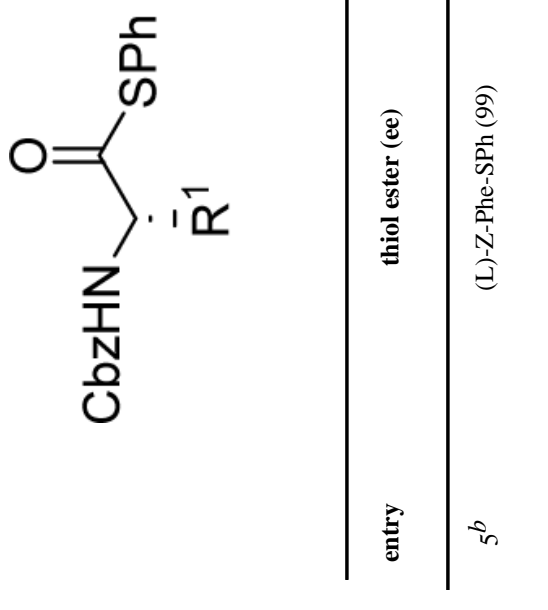

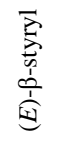
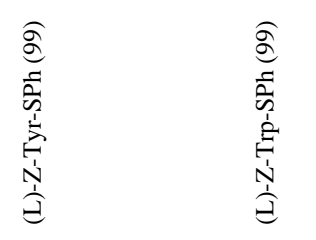

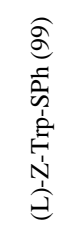




O=

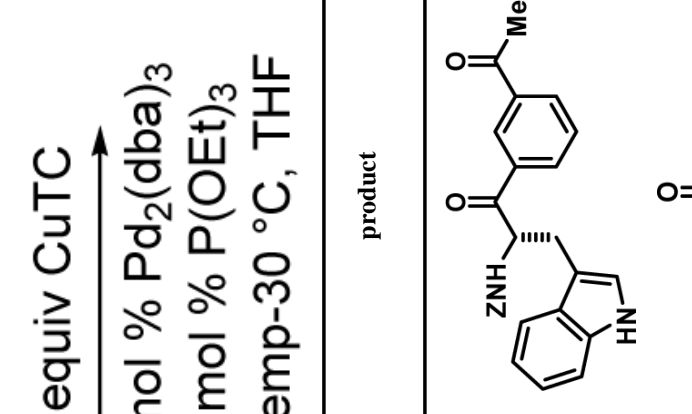

<smiles>N#C[C@@H](Cc1cccc2ccccc12)C(=O)c1ccco1</smiles>


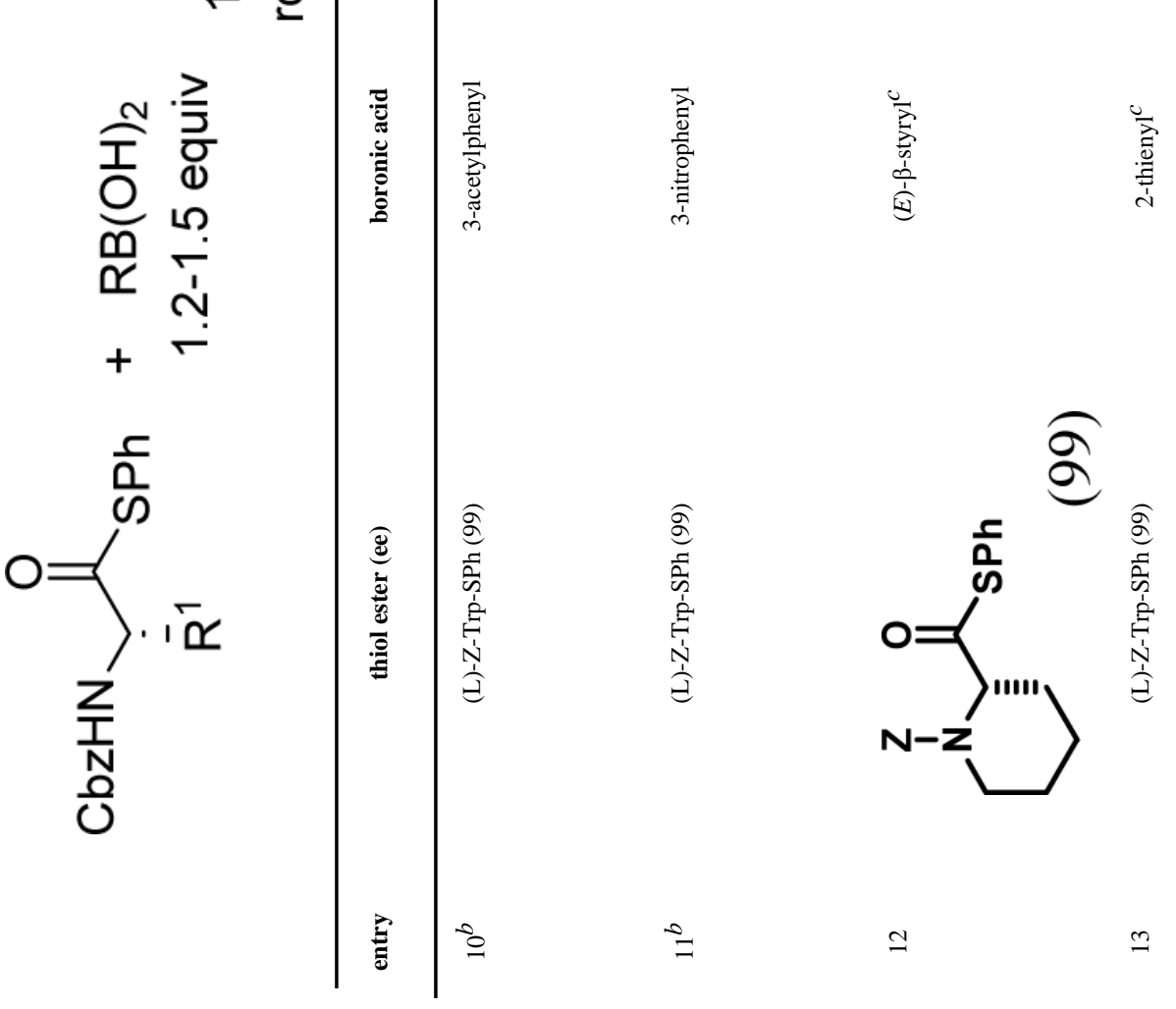


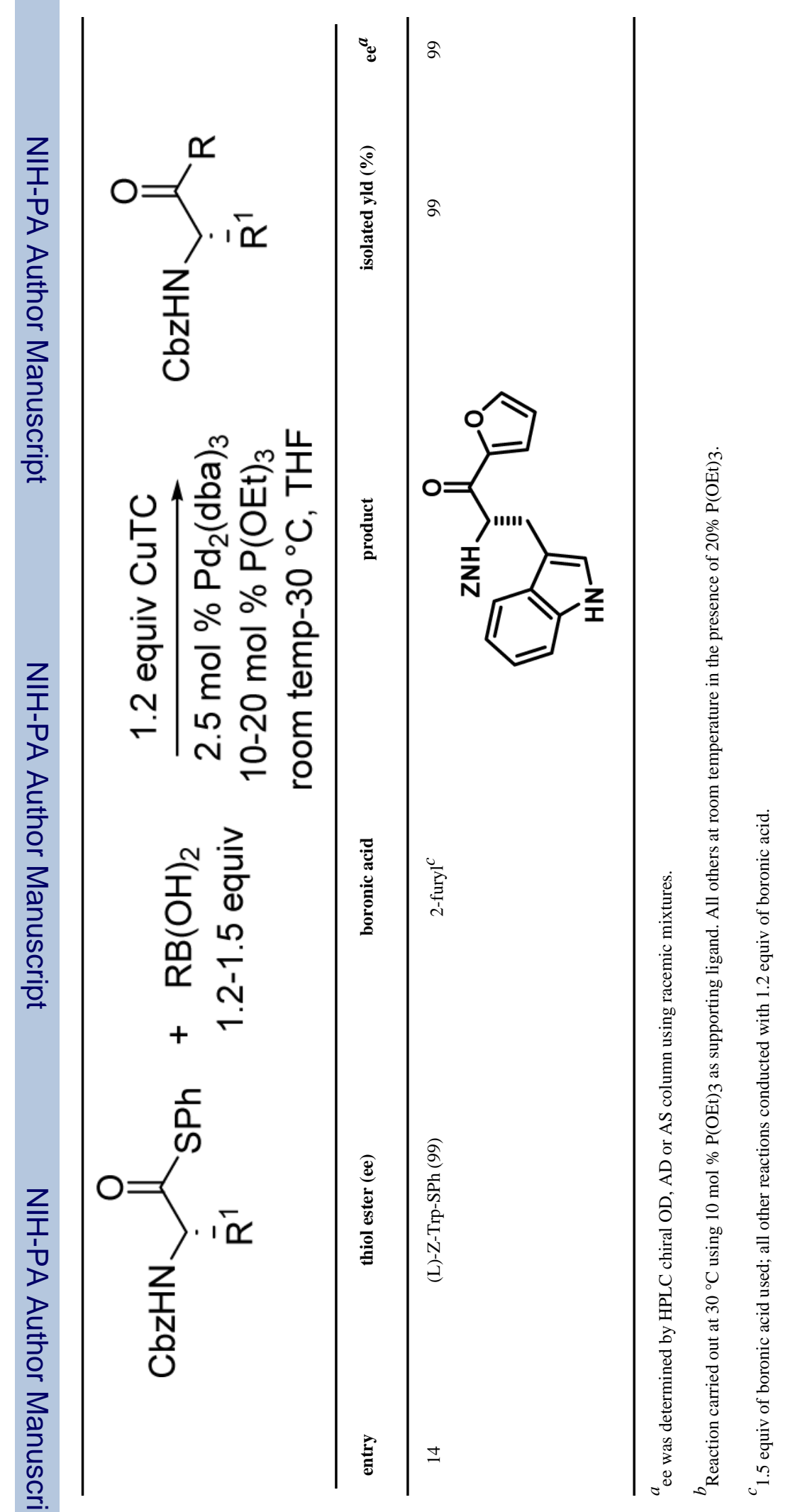


Table 4

Probing Dipeptide Thiol Ester-Boronic Acid Cross-Coupling. Influence of Boronic Acid Stoichiometry on the CrossCoupling Yield

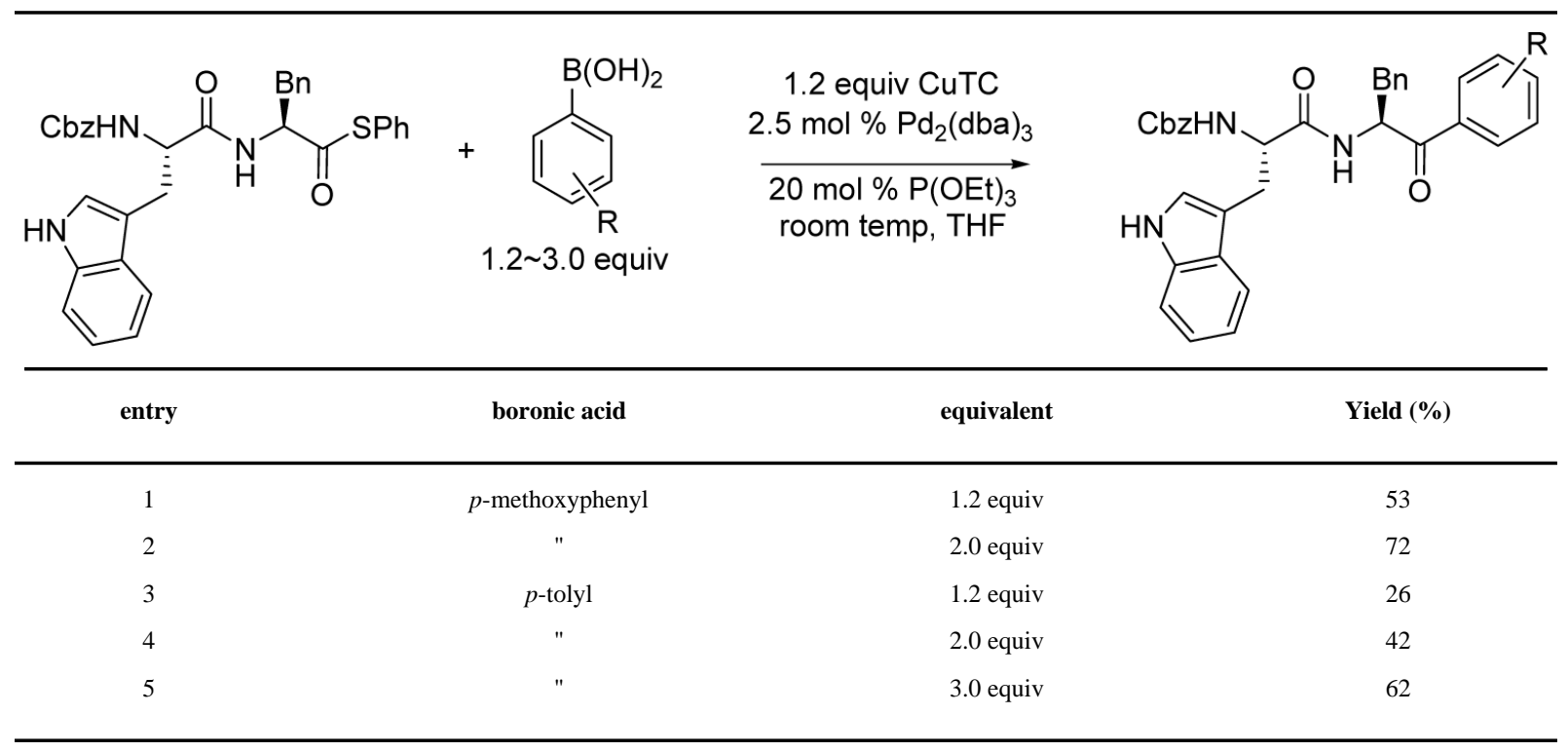


Table 5

Structures, Isolated Yields, and Diastereomeric Purity of Peptidyl Ketones

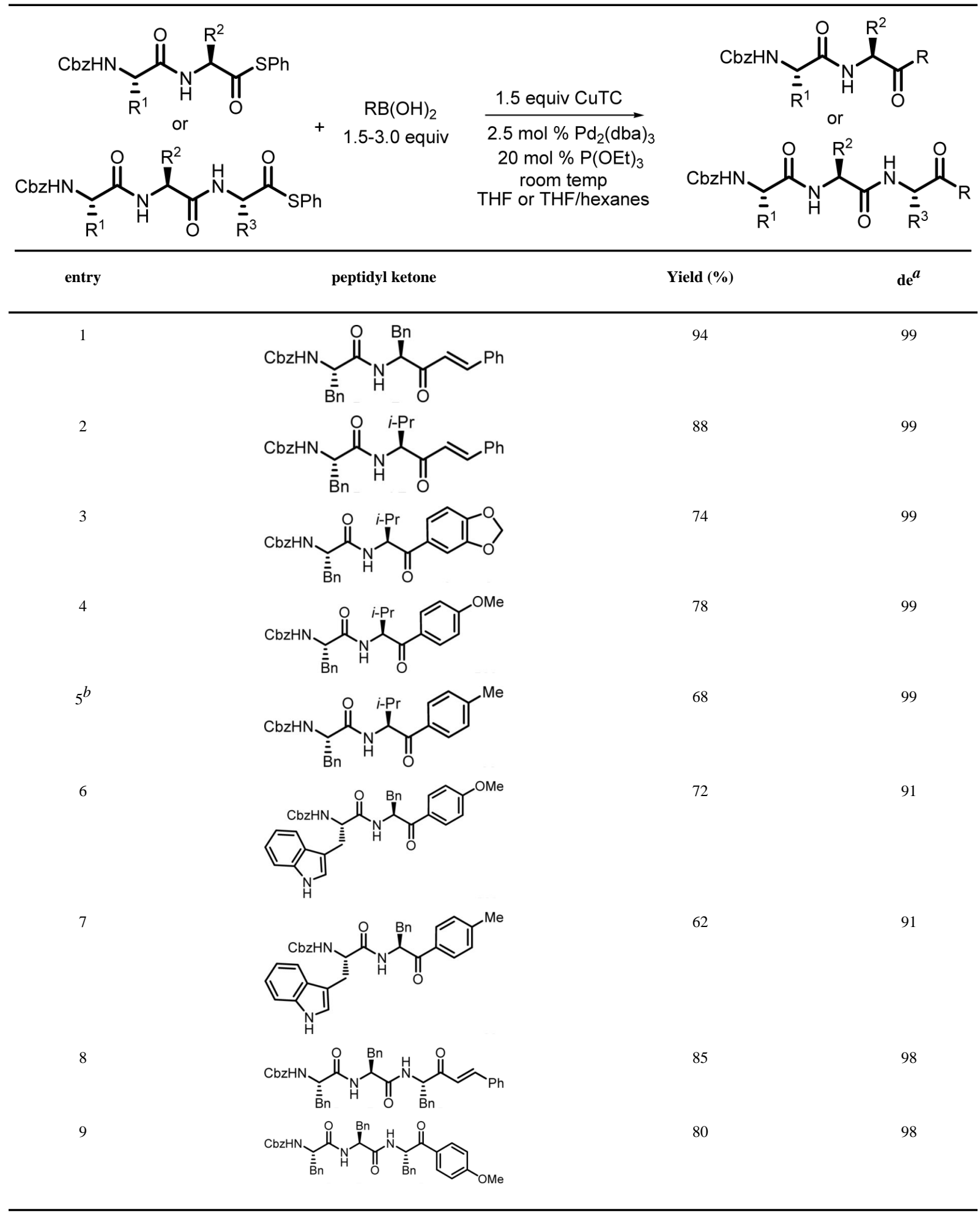

${ }^{a}$ The de of each ketone is identical to the de of the thiol ester reactant; no epimerization occurred during the cross-coupling reaction.

${ }^{b}$ The reaction was carried out in 1:1 THF:hexanes. 